\title{
Household Food Security through Cooperatives in Northern Ethiopia
}

\author{
Woldegebrial Zeweld Nugusse ${ }^{1 *}$, Guido Van Huylenbroeck ${ }^{1}$ and Jeroen Buysse ${ }^{2}$ \\ ${ }^{I}$ Department of Natural Resources Economics and Management, Mekelle University, Mekelle, Ethiopia \\ ${ }^{2}$ Department of Agricultural Economics, Ghent University, Ghent, Belgium
}

\begin{abstract}
The government of Ethiopia has technically and financially encouraged cooperative societies in order to play significant role in ensuring food security. This study thus investigated the impact of cooperative societies on ensuring household food security in Tigray region using 400 sample households, household survey and Heckman two-stage model. The study confirms that cooperatives have contributed substantial roles in ensuring food security in the study area through increasing income sources, creating employment, and supplying inputs and consumer goods at reasonable price. The adult-equivalent income and expenditure of cooperative members are statistically different from the nonmembers during 2009 and $2010(\mathrm{P}<0.05)$. The inter-time comparison method indicates that there are statistically significant difference in per adult- expenditure and -income of the members before and after joining the cooperatives $(\mathrm{P}<0.05)$. The study found that $21 \%$ of the members are food insecure while the figure for the nonmembers is $36 \%$ (significance difference at $\mathrm{P}<0.01$ ). Cooperative society is among the major determinant of household food security in the study areas $(\mathrm{P}<0.05)$. This justifies that expansion of cooperative societies is an important tool to minimize the food insecurity problem in the country. The study is also vital for policy makers, students and researchers to draw lessons on how cooperative societies reduce food security. Thus, the government should give attention for the expansion and diversification of cooperatives in order to join more people and then achieve food security.
\end{abstract}

Keywords: Heckman model, cooperatives, food security, cooperation

\section{Introduction}

The agriculture sector is the backbone of the Tigray region (Ethiopia). It had a share of $45 \%$ of the regional GDP, $85 \%$ of the regional export earnings, $38 \%$ of the government taxing revenue and $85 \%$ of the employment opportunity in 2010. It also provides input for the non-agriculture sector (MoFED, 2011). However, its productivity is very low because of high dependence on backward technology, unpredictable natural factors and family labor. As a result, the region has encountered with recurrent drought and food insecurity problem (Mitiku, 2006). More than $35 \%$ of the regional population lived below the regional poverty line (MoFED, 2011).

As a solution, the regional government associated with concerned organization has given priority for the establishment and expansion of cooperative societies, small business enterprises and irrigation farming (Tadesse, 2002) because these are considered an engine for ensuring food security, reducing poverty and bringing sustainable development given land, labor and water resources of Ethiopia. By taking this as good initiative for development, the federal government has approved principles, regulations and directives of cooperative societies under proclamation
No. 147/1998 in 1998. The proclamation allows persons who live or work within a particular area in the country to voluntarily and democratically establish a cooperative society (FCC, 2010).

Preparing and approving cooperatives act at a national level is a common practice in other countries since cooperatives are considered as a basis for development. For example, the South African government is promoting cooperative organizations as a major actor in economic and social development through creating employment, generating income, enhancing small-scale farmers and eradicating poverty (RSA 2005). Different studies show a positive and significant effect of cooperative societies on poverty reduction through employment generation, women empowerment and market stabilization (Coon \& Leistritz, 2001; Merrett \& Walzer, 2001, Groves, 1985; Kebeer 2005, Baviah, 2006, Sobrado, 2000; Hallett, 2001; Glasbergen, 2000; Pichiavaram, 2003; Dayandiach, 2004 \& Fairbairn, 1999).

Other studies have found insignificant contribution of cooperative societies to ensuring food security and reducing poverty because of heterogeneous membership, organizational management, passive participation, absence of trust among members, equalsharing of dividend regardless the level of participation 
and so forth problems (Dongfeng, 2012, Andrew, 2001, Guest, 2004, Max et al. 2011, etc.). The government of Tigray region (Ethiopia in general) has invested more for cooperative societies regardless these mixed and contradiction research findings. Cooperative members have provided various technical, material and financial incentives. The government has also provided cooperative societies a legal supportive framework and accordingly; many people have organized in groups and established various cooperatives. The number and types of the cooperative societies have dramatically increased (FCC, 2010).

However, the impact of the cooperatives on food security has not studied. The available cooperative studies (literatures) in the region are Veerakumaran, 2003, Fitsum, 2003a \& Tadesse, 2002, which were dealt about the historical movement and development of cooperatives in the country starting from 1950s. For this fact, the aim of this study was to investigate the impact of cooperative societies in ensuring household food security using household survey, and Heckman selection two-stage model. Consequently, the study enabled to produce relevant research outcome for policy makers, interventionists and other economic actors.

\section{Cooperative Empirical Study}

Cooperative society defined as an autonomous association of persons united voluntarily to meet their common economic, social and cultural needs and aspirations through a jointly owned and democratically-controlled enterprise (ICA, 2005). Food insecurity also defined as a limited availability of nutritionally adequate and safe foods (Carlson, 1999), and insufficiency of money to meet dietary energy requirement (Tarasuk, 2001). Many studies have been conducted on the cooperatives and household food security. Zeuli (2002) made a study on the importance of cooperatives for employment using the Social Accounting Matrix in the rural areas of Wisconsin state via cross section data. 798 cooperatives have generated 17413 full-time and 60211 part-time jobs. He concluded that the cooperatives are a basis for unemployment reduction.

Using 1996 and 2001 years panel data, Coon and Leistritz (2001) studied the importance of cooperatives in Minessesota. The study was covered 337 cooperatives, of which $58 \%$ were agricultural cooperatives. The result shows that the cooperatives have provided 9078 direct jobs and 42290 secondary (induced) jobs. As a result, the livelihood of the employed individuals has grown by about $1.2 \%$ per annum. They concluded that cooperative societies have virtually solved unemployment problem in the state. Merrett and Walzer (2001) also undertook a study in the same state by considering 425 cooperatives using the same methodology and concluded that cooperatives have significantly induced the expansion of locally based businesses, which are generated huge job opportunities for the local communities.

Groves made a study about the role of cooperatives on market stabilization in Madison city, USA. The study randomly selected 24 types of cooperatives. The finding indicated that cooperatives have considerably stabilized the local markets through distributing inputs to farmers and outputs to customers at the reasonable prices, and providing economic agents with timely and relevant market information. By serving as an intermediary agent between the producers and consumers, cooperatives have met the challenge of market failure. He concluded that cooperative institutions are the foundation of better life in rural communities by stabilizing the local and ever fluctuating market (Groves, 1985).

Most women in developing countries have limited access to productive resources, which hampered them not to earn incomes and actively participate in economic and political conditions (Kebeer, 2005). In this situation, cooperative institutions have played significant roles in empowering poor women. UNDAW (2001) defined empowerment as the process by which people who are powerless become aware of the power dynamics at work in their lives context, develop the skill and capacity for gaining some reasonable control over their lives, exercise this control without infringing upon the rights of others and support the empowerment of others.

Women in Bangladesh were highly discriminated and were not participating in productive activities. The government motivated them to organize themselves under cooperatives and solved their problem together. They have organized and formulated cooperative institutions. Hence, they have addressed gender inequalities by mobilizing saving from members to develop members' businesses. Because of the cooperatives, women are able to visit the health center without getting permission from male household heads (Baviah, 2006).

Cooperatives are essential to escape the limitation of isolation, financial shortage and lack of experience by capturing of economies of scale and scope (Sobrado, 2000). Hallett (2001) made a study on the significance of cooperatives on environment rehabilitation and natural resource conservation. He found that cooperatives have provided nursery services in rural Canada. They have also participated in promoting integrated pest management, supporting soil and water conservation, and promoting a low disturbance conservation tillage system. For instance, cooperatives in Western Europe have initiated farmers to integrate environmental values into their production system (Glasbergen, 2000). Cooperatives have also 
addressed environmental repercussion of industrialized agriculture, including the waste-management problem of concentrated animal feeding operation(Walter, 2003).

Pichiavaram (2003) has made a comparative study between state and cooperative farming system contribution to gross domestic product in India using panel data from 1994 to 2002. The result indicated that agricultural cooperatives have produced more output with higher productivity than state owned agriculture, with an average annual growth rate was $5 \%$ higher than the state owned. The cooperative sector has also contributed more to GDP (14\%) and agriculture output (37 \%) than state agriculture, which respectively contributed $1.2 \%$ and $9 \%$.

A similar study was carried out in the Sudan about the roles of agricultural cooperatives in the national economy using four consecutive years' panel data (2000-2003). 97 sample cooperative societies were selected for the study. The result showed that these cooperatives have contributed on average about $23 \%$ of the gross national product. It also indicates that the average annual expenditure and income of members have dramatically improved in a short period by $13 \%$ and $19 \%$, respectively. The study concluded that agricultural cooperatives are important for expanding household income and expenditure (Dayandiach, 2004).

Another study was conducted in Canada by using eight years panel data on the roles of cooperative societies on the economic growth. The study selected 270 different cooperative societies. The result indicates that agricultural cooperatives have contributed $27 \%$ of the gross agricultural output and $2.5 \%$ of the national GDP. The annual income and expenditure of members have increased by $5 \%$. Consequently, governmental and other organizations have provided substantial support for this sub sector to facilitate the growth rate of the economy. The study concluded that expansion of agricultural cooperatives is a good means of achieving food self-sufficiency at a household level (Fairbairn, 1999).

In Israel, there was a frequent and serious food insecurity problem while the state-owned agriculture was the dominant. In order to solve the problem, the government has shifted its attention to cooperative agriculture and has encouraged cooperative societies, which, after that, accounted on average for $25 \%$ of the total agricultural output and $3.9 \%$ of the gross domestic product of the country. The livelihood of members has substantially increased. The authors concluded that cooperatives have been instrumental in solving the precarious food situation problem in the country (Smeeding et al. 1990). Generally, cooperative societies have played significant roles in attaining food security through different initiatives.

\section{The Study Area}

This study was conducted in Tigray region (Northern Ethiopia). It extends from $12^{0}$ to $15^{0}$ northern latitude and $36^{\circ} 30^{\prime}$ to $41^{\circ} 30^{\prime}$ eastern longitude (Bhatta, 2004). The region has common borders with Amhara region, Afar region, Eritrea, the South Sudan and the Sudan in the south, east, north, northwest and west, respectively. It has six administrative zones, 36 woredas (districts) and 550 tabias (villages). The region had a total population of about 5.1 million in 2010 , of which, $51 \%$ were females and $80 \%$ lived in rural areas. More than $85 \%$ of the population depend their livelihood on agriculture sector. More than half of the total population lived in absolute poverty and are food insecure (CSA, $2011 \&$ MoFED, 2011).

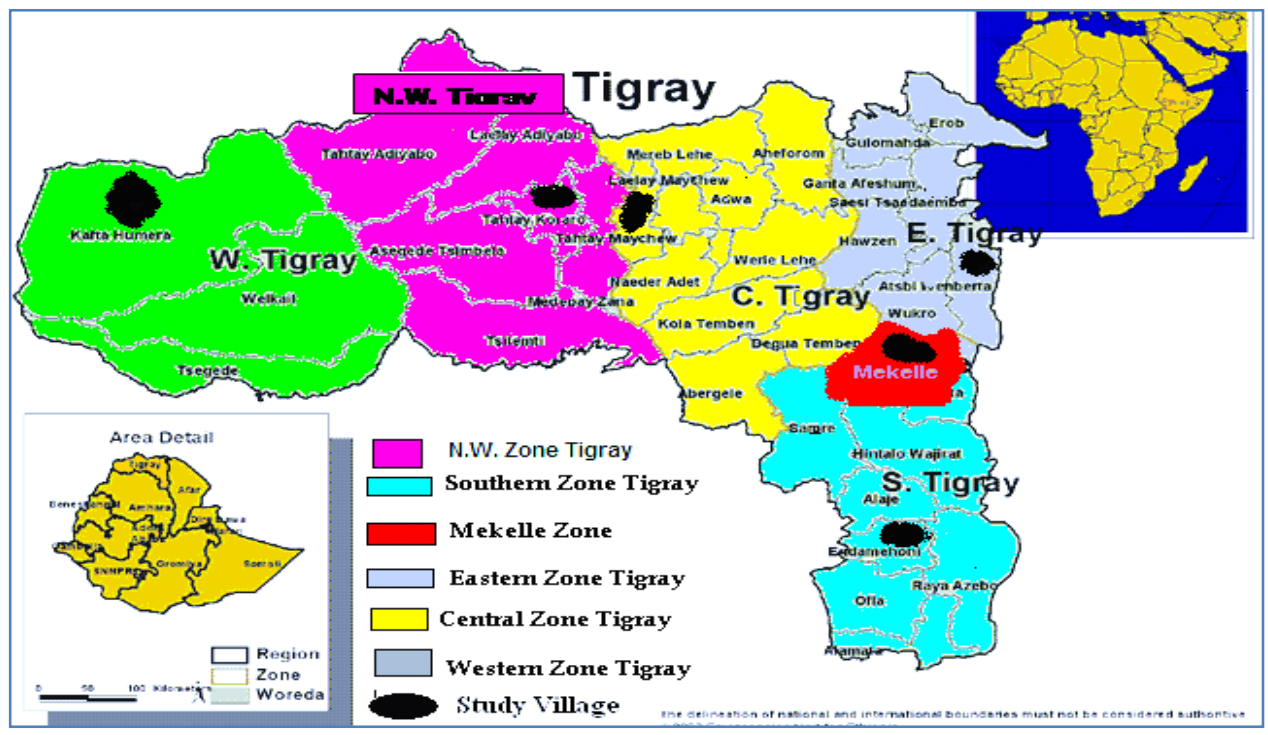

Figure 1. Map of Tigray region (Northern Ethiopia). 


\section{Sampling Technique}

The study was randomly selected one woreda from each administrative zone of the region. The study also randomly selected a tabia from each woreda. The study was used randomness because they are cooperatives in all tabias though differs in financial and other capacities. The study randomly selected 400 households. Accordingly, the sample households were 160 member households and 240 nonmember (control group) households. Thus, the study was used three-stage sampling technique for the household sample unit.

There are many and different types of cooperative societies in the region. According to the Annual Report of the Regional Cooperative Bureau, there are more than 20 types of cooperative societies (2010). The financial resources retarded to consider all types. Accordingly, the study was purposively selected irrigation, beekeeping and multipurpose cooperative societies using more capital budget, tabia level of distribution, number of members and number of employees. Finally, the study arranged six group discussions at woreda level with purposefully selected key informants from cooperatives, non-government offices, communities, local leaders and government offices.

\section{Data Collection Method}

The study was used different data collection methods to collect reliable and high-quality data. Household survey was used to gather demographic data, socioeconomic variables, cooperative variables, institutional data, services data, village variables, food security variables and so on. The questionnaire was pretested with 10 randomly selected households to determine the ability of the respondents in answering questions, and test the adequacy of the questions.

A group discussion was also arranged with representatives from cooperative members, local communities, non-government offices, local leader committee and government offices to collect additional information and inner feeling. Moreover, intensive interview was made with key informants to collect detailed information for case study purpose. Finally, the study was employed desktop survey to collect secondary data from journals, cooperative records and other documents to evaluate the previous studies with the present study.

\section{Econometric Model Specification}

This study used two-sample t-test to compare the income and expenditure between members and nonmembers using 2009 and 2010 as well as estimate the income and expenditure difference of the members between the pre-and post-intervention period. The study also used the Heckman model to examine the impact of the cooperative societies on the household food security from among other household food security influencing factors. The dependent variable of the study is expressed as indicated in equation 1

$$
Y_{i}=\beta_{0}+\sum_{i=1}^{n} \beta_{i} X_{i}+\varepsilon_{i} \quad \text { where }, \quad \varepsilon_{i} \approx N\left(0, \delta^{2}\right) \quad i=1,2,3, \ldots n \ldots \ldots \ldots \ldots \ldots \ldots \ldots \ldots . .1
$$

Where $Y_{i}$-the dependent variable, $X_{i}$ is a vector of observed explanatory variables and $\varepsilon_{i}$ is the error term of the study for ach respondent $i$. The study measured the food security dependent variable using the demand-side of expenditure approach because supply side doesn't show the household entitlement over the production supply (Fitsum, 2003b), expenditure approach better captures long-run welfare and better reflects the household's ability to meet their basic needs (Rueben et al. 1978) and the respondents may not tell the exact number they have earned and may also not remember the amount of income that they have earned (Fitsum, 2003b).
The study also used adult-equivalent it better captures unequal share of members in the income and expenditure (Fitsum, 2003b) whereas household size method considers all members (baby, child, adult and old) of the family having the same earning and consumption capacity. The average adult-equivalence scale is computed as adult male and female (15-60 years) is assigned 1; male above 60 years is 0.67 ; female above 60 years 0.60 ; child (10-14 years) is 0.50 ; child ( 5 - 9 years) is 0.35 and child below 4 years is 0.20 (Sendalo, 1995). The average adultequivalent expenditure (HFS) of 2009 and 2010 years is expressed as

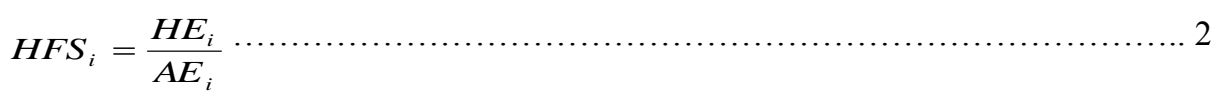


Where, HFS is the outcome variable, which is the ratio of total food and non-food expenditure (HE) consumed by all members of the household per the

$$
H F S_{i}=\beta_{0}+\sum_{i=1}^{n} \beta_{i} X_{i}+\delta D_{i}+\varepsilon_{i}
$$

Where, $D_{i}$ is a dummy variable that is assigned one for households participating in cooperatives otherwise zero, and $\delta$ estimates the effect of participation in cooperative. This is, however, treated as endogenous because the probability to participate or not is based on observable and unobservable adult-equivalent family sizes (AE) of the household. The model of the study can be written below by combing equation 1 and 2

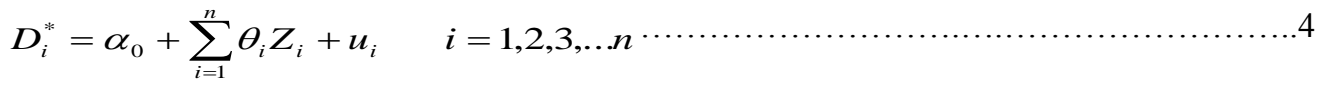

Where, $\mathrm{Z}$ includes membership in rural association, attending public meeting, education, access to cooperative training, information access $(\mathrm{TV}$, radio, mobile, etc), service access (transport, extension, electricity), member of administrative committee, farmland ownership and so forth. This equation is used to construct a selectivity term know as "Mills

$$
\lambda=\frac{\phi\left(\theta, Z_{i}\right)}{\psi\left(\theta, Z_{i}\right)}=\frac{\phi(-\theta Z)}{(1-\psi(-\theta Z))}
$$

Where, $\psi$ and $\phi$ are the functions of density and cumulative distribution of a standard normal variable, respectively. With the inclusion of this extra term, the coefficient in the second stage 'selectivity corrected' equation is unbiased (Greene 2003). The cooperative

$$
E\left(H_{F} / D_{i}^{*}>0\right)=\beta_{0}+\sum_{t=1}^{n} \beta_{t} X_{i}+\delta_{\varepsilon u} \delta_{u} \lambda\left(-\theta Z_{i}\right)+e_{i}
$$

food security equation is only observed when $D_{i}^{*}>0$ and the equation after controlling the mill ratio becomes

Ratio". This selective term was included in the second equation as independent variable to reflect the degree of sample selection bias. Significant Mills Ratio coefficient indicates the existence of an unobserved selectivity bias and confirmation the appropriateness of the Heckman model (Greene 2003). The inverse Mills ratio is given as
Where, $\beta$ and $\gamma$ are the vectors of parameters which measure the effect of variables $\mathrm{X}$ and $\mathrm{Z}$. $\gamma$ refers the average net wealth benefit from cooperatives. This expression of conditional expectation shows that $W_{i}$ equals $X \beta$ only when the errors $\varepsilon_{i}$ and $u_{i}$ are noncorrelated $\left(\sigma_{\varepsilon u}=0\right)$ otherwise. Therefore, $e_{i}$ is the distributed error term $N\left(0, \sigma_{\varepsilon}\left(1-\sigma_{\varepsilon u}(\lambda(\lambda-\theta Z))\right)\right)$ and estimate $\beta$ and $\beta_{\lambda}=\sigma_{\varepsilon u} \sigma \varepsilon \lambda$ using TwoStage Least Square model of $W_{i}$ over $\mathrm{X}$ and $\lambda$. All the continuous explanatory variables in the second equation were expressed in natural logarithms.

\section{Respondent Profile}

Household demographic information includes sex, occupation, education, special skill and family size. Household rural assets also include livestock, farmland, income and wealth. The study result shows that male-headed households account about $65 \%$. The household average age is 45 years, and it ranges from 20 to 76 years. $60 \%$ of the households do have special skills such as carpenter, mason, pot making, weaving, hair dressing and traditional healer (Table 1).

The table also shows that the educational background of the households varies from illiterate to literate like in the religious school, literacy campaigns, elementary school, secondary school, and vocational and technical institution. $53 \%$ of the sample households are literate in different educational levels. The average household members are 5.3 and the average family dependency ratio (proportion of children below 18 years and elders above 60 years per adults between 18-60 years) is 1.1. The household consumer-worker ratio (total family sizes per number of workers in the family cell) is on average 1.2.

However, not all members of the family are economically productive because there are physically unproductive members due to age and sex difference (Sendalo, 1995 \& Fitsum, 2003b). Table 1 show that 
the labor-adult equivalence ratio in the study area is 4.2. Tropical Livestock Unit (TLU) is an international unit used to measure for livestock. 1 TLU equals 1 camel; 0.7 ox/cow; 10 sheep/goats; 0.5 donkey/bull; 0.45 heifer/calf; 0.7 mules; 0.8 horses or
100 chickens (Bharat 2004). Land and animals are the basis of rural livelihood. Livestock, farmland and number of oxen in the study areas are 3.4 TLU, 2.5 tsimad and 1.6, respectively.

Table 1. Household demographic and socioeconomic statistics (Mean value)

\begin{tabular}{|c|c|c|c|c|}
\hline Household Head Variables & Members $(n=160)$ & $\begin{array}{l}\text { Nonmembers } \\
(\mathrm{n}=240)\end{array}$ & $\begin{array}{l}\text { Total } \\
(\mathrm{n}=400)\end{array}$ & T-Value \\
\hline Age & 44.4 Years & 45.8 Years & 45 years & 1.27 \\
\hline Male- headship & $65 \%$ & $66 \%$ & $65 \%$ & 0.93 \\
\hline Special skill & $57 \%$ & $62 \%$ & $60 \%$ & 0.35 \\
\hline Literate rate & $53 \%$ & $53 \%$ & $53 \%$ & 0.89 \\
\hline Adult equivalence & 4.63 & 4.78 & 4.2 & 1.54 \\
\hline Average family sizes & 5.36 & 5.23 & 5.3 & 1.45 \\
\hline Dependency ratio & 1.12 & 1.14 & 1.1 & 1.20 \\
\hline Consumer worker ratio & 1.27 & 1.23 & 1.2 & 0.52 \\
\hline Livestock equivalence & 3.63 & 3.24 & 3.4 & $5.81 * * *$ \\
\hline Average farmland & 2.52 & 2.47 & 2.5 & 1.12 \\
\hline Number of oxen & 1.81 & 1.45 & 1.6 & $4.49 * * *$ \\
\hline
\end{tabular}

***: Significant at $1 \%(\mathrm{P}<0.01 \%)$

The pooled-variance two-sample t-test shows that there are no statistically significant differences in literate rate, family sizes, household age, special skill, household headship, adult equivalence, farmland, consumer-worker ratio and dependence ratio between member and nonmember households at 5\% significance level. In contrast, there are statistically significant differences in a number of oxen and livestock equivalent (using 2009 and 2010 data) in the study area between member and nonmember households at 5\% significance level.

\section{Household Welfare Situation}

The study examined the different household income sources. Rural people earn incomes from on-farm and off-farm activities, food-for-work, safety net programs, remittance and self-employment like a mason, carpenter, tailor, hair dressing, weaving and so forth (Fitsum, 2003b). The group discussants of the study explained that cooperative members have earned additional incomes from the cooperatives in the forms of employment, financial support and dividend share. Nonmembers may not, however, earn these incomes. Thus, cooperative societies are an important and additional source of household incomes in the study areas.

Table 2. Comparison of income and expenditure of members before and after intervention.

\begin{tabular}{lccc}
\hline Welfare indicators & Before Joined & After Joined & T-Value \\
\hline Incomes & 4912 & 8639 & $10.028^{* * *}$ \\
Expenditure & 4107 & 6000 & $8.499 * * *$ \\
\hline$* * *:$ Significant at $1 \%(\mathrm{P}<0.01 \%)$. & & &
\end{tabular}

The study compared the present incomes and expenditure of the members (2009-2010 years data) with the baseline data, which found from the cooperatives and the woreda bureau of cooperative. Table 2 demonstrates that the present income and expenditure of the members have substantially increased compared to the situation before intervention into cooperatives. The mean income difference between the two periods was about Birr 3700, and similarly, it was about Birr 1900 for the mean expenditure difference. The two-sample t-test shows that there is statistically significant difference in average income and expenditure between the two periods at $1 \%$ level.

Table 3. Comparison of income and expenditure between members and nonmembers.

\begin{tabular}{llll}
\hline Welfare indicators & Members & Nonmembers & T-Value \\
\hline Incomes $(2009-2010)$ & 8639 & 5866 & $6.343^{* * *}$ \\
Expenditure $(2009-2010)$ & 6000 & 4539 & $4.209^{* * *}$ \\
\hline
\end{tabular}

***: Significant at $1 \%(\mathrm{P}<0.01 \%)$. 
A comparison of income and expenditure between members and nonmembers using 2009 and 2010 years data was another objective. Table 3 indicates that the average income of the member was about Birr 8600 and Birr 6000 for a nonmember. On the other hand, the nonmember has, on average, spent about Birr 4500 and the member has spent about Birr 5800 on food and nonfood items. The pooled twosample t-test illustrates that there is statistically significant difference in the average income and expenditure between the member and nonmember households using 2009 and 2010 years data at 1\% significance level. Therefore, cooperative societies are the basis for an additional incomes and expenditure.

The average per-adult-equivalent household income per annum during 2009 and 2010 for the members was Birr 1866 while the corresponding figure for nonmember was Birr 1228. Similarly, the average per-adult-equivalent expenditure per annum during the same years for members was Birr 1296 and for nonmembers Birr 950. Statistically significant difference between members and nonmembers exit in both per-adult-equivalent cases. This figure can help to estimate the level of household food security in the areas. Fitsum (2003b) described that minimum food consumption expenditure per-adult-equivalent above which a household is considered to be food secure was calculated based on the estimated cost of acquiring the recommended daily calorie allowance (2200 kcal per-adult-equivalent per day).

The cut-off value of the adult-equivalent expenditure is calculated following the Greer and Thorbecke (1986) food energy intake method of measuring household food security. In Ethiopia based on 2009 calculation, it is estimated to be Birr 900 per-adult-equivalent per annum (CSA 2011). Accordingly, the study found that $21 \%$ of the members are food insecure while the figure for the nonmembers is $36 \%$. Thus, households who joined cooperatives are more food secure than households not joined, similar finding to Zhao and Xuchu (2011) found households who are members of cooperatives are much more food secure than the nonmember households; and cooperatives are a miracle solution for poverty reduction in rural china.

Participants in the group discussion and household survey illustrated that the cooperatives have brought positive changes on incomes and expenditure, which enable them to send children to school, cover medical expenses and take balance diet. Combing Table 2 and Table 3, the income and expenditure of members are about Birr 2700 and
1400 higher than the nonmembers. For example, Hagosa Tesfay had an average income of Birr 35000 in 2009 and 2010 while it was Birr 200 in 2000 year, before she joined Hiwane Multipurpose Cooperatives. She has received a Madelia and Birr 1500 award in 2009 from the regional government for her tireless commitment to escape from poverty.

\section{Cooperatives and Food Security}

The study explored the impact of cooperatives on food security. Studies proved success record of cooperatives in the fight against poverty in the whole sub-region, Palestine, South Lebanon and Iraq (Lee 2001 and Birchall 2004). Table 4 indicates the cooperative participation and food security equations of the Heckman two-stage model of the study. The former equation shows the major factors that affect households to join cooperative societies. The coefficients of the participation equation in the table refer to the marginal effect $\left(\partial \mathrm{D} / \partial \mathrm{X}_{\mathrm{i}}\right)$ of the variables.

Household special skill, membership in rural association, frequent attending public meeting, household head education, training relatedcooperative, information access ( $\mathrm{TV}$, radio and mobile), access to main market, farmland ownership, access to services (transport, extension, electricity), farmland ownership and number of school children are the most important and instrumental variables that affect rural people to join into cooperatives. Some variables like market access, farmland and training are similar to Atmis et'al (2009) findings. The probability to join cooperatives is $32 \%$ higher for households who are members of the rural association compared to nonmember households. Thus, the rural associations are important organizations to establish and expand cooperative societies.

The finding shows that households with special skill are unlikely to join cooperatives. The group discussants explained that households have earned immediate incomes from the skill works than from the cooperatives. The probability to join cooperatives is $88 \%$ lower to rural people with special skill than with no skills. The rate of migration from rural to urban areas is significantly higher for households with no farmland than households with farmland (Todaro \& Smith 2011). This study confirms that landless households don't want to join cooperatives because they prefer to move to towns to search jobs and better life. The probability to become a member of cooperative is $63 \%$ lower to landless rural people than with land. 
Table 4. Estimation coefficient of the Heckman selection model (participation and outcome).

\begin{tabular}{|c|c|c|c|}
\hline Household Parameters & Coef. & Std. Err. & $\mathrm{P}>|\mathrm{Z}|$ \\
\hline \multicolumn{4}{|l|}{ Food Security Equation } \\
\hline Male-head household & 0.0258 & 0.1432 & 0.859 \\
\hline Household Age (year) & -7.5250 & 4.4006 & $0.087 *$ \\
\hline Household Agesquare & 0.9785 & 0.3097 & $0.001 * * *$ \\
\hline Farmland Sizes (tsimad) & 0.0355 & 0.0112 & $0.002 * * *$ \\
\hline Family Sizes (number) & -0.1789 & 0.0234 & $0.000 * * *$ \\
\hline Literate household & 0.0842 & 0.0432 & $0.062 *$ \\
\hline Membership in cooperative $(1=$ member $)$ & 0.3132 & 0.0287 & $0.034 * *$ \\
\hline Livestock Equivalent (TLU) & 0.2048 & 0.0785 & $0.009 * * *$ \\
\hline Number of Oxen (number) & 0.3239 & 0.0815 & $0.022 * *$ \\
\hline Access to alternative credits & 0.0676 & 0.1300 & 0.101 \\
\hline Woreda Market Access (km) & 0.1809 & 0.1321 & $0.100 *$ \\
\hline Pure Water Access (minute) & 0.3908 & 0.1406 & $0.006 * * *$ \\
\hline Services access (Transport, Extension, Electricity) & 0.7827 & 0.2533 & $0.002 * * *$ \\
\hline \multicolumn{4}{|l|}{ Selection Equation } \\
\hline Household with special skill & -0.880 & 0.176 & $0.000 * * *$ \\
\hline Members in rural associations & 0.317 & 0.183 & $0.000 * * *$ \\
\hline Often attending public meetings/workshops & 0.340 & 0.195 & $0.000 * * *$ \\
\hline Members in administering committee & 0.129 & 0.168 & 0.444 \\
\hline Household head education & 0.457 & 0.165 & $0.011 * *$ \\
\hline Access to cooperative trainings & 0.436 & 0.172 & $0.045^{* *}$ \\
\hline Information access ( $\mathrm{TV}$, radio, mobile, etc.) & 0.901 & 0.188 & $0.000 * * *$ \\
\hline Access to market $(\mathrm{km})$ & -0.266 & 0.370 & $0.050 * *$ \\
\hline Farmland ownership (landless) & -0.633 & 0.291 & $0.000 * * *$ \\
\hline Farmland sizes & 0.140 & 0.051 & $0.005^{* * *}$ \\
\hline Children and school (number) & -0.079 & 0.051 & $0.011 * *$ \\
\hline Lambda (mills) & 0.426 & 0.0785 & $0.034 * *$ \\
\hline
\end{tabular}

Rho $=0.742$ Sigma $=0.574$ Prob $>$ chi $2=0.000 * * *$

The same table explains that information access through training, information tools and exposure visit, and education enhances the awareness of rural people about the importance of cooperatives. Van argued that absence of training and experience sharing discourages joining cooperatives (2005). The probability to join cooperatives is $90 \%$ higher to well-informed households than households with no access to information. Similarly, the likelihood of literate households to become a member of cooperative is $46 \%$ higher compared to illiterate households.

Living near to main market improves the awareness and the participation of the people in market-oriented economic activities (Bhatta, 2004). The study shows farmers who live around the woreda market prefer to participate in small business and causal works rather than joining and spending time in cooperatives. Households with large farmland are also unlikely to join into cooperatives compared to households with small farmland (below the average). Rural people with more than three children (average children number) at school have less probability to join cooperatives than households with fewer children at school. Pérotin (2006) found low wealth; higher risk aversion and lack of credit access are an entry point into cooperatives. More educated and asset-rich households are more likely to participate in cooperatives (Vargas, 2008).

The coefficient of the lambda is statistically significant at $5 \%$ significance level. This confirms the presence of sample selection bias, and the appropriateness and relevance of the Heckman selection model to address the sample selection bias. Table 4 demonstrates the result of the cooperative food security equation. The major explanatory variables that have a statistically significant impact on the household food security in the study areas are farmland sizes, number of oxen, livestock (TLU), household age, education, family sizes, member of the cooperatives, access to woreda market and potable water, and availability of infrastructure services like road, extension, electricity and communication services.

The cooperative societies have a positive and significant impact on household food security. Table 4 shows that the probability of rural people attaining food security is $31 \%$ higher for active cooperative members than the nonmember households. Tanguy studied the impact of cooperatives on smallholders' commercialization behavior and found that educational level, radio ownership, nonfarm incomes, landholding and livestock are the main determinants 
(2008). Households with more oxen and livestock, and large farmland are more food secure and less vulnerable compared to households with no oxen (Bhuyan, 2000 \& Broussard, 2012). Therefore, cooperative members are relatively more food secure than nonmembers.

The group discussants and the household survey respondents explained that cooperative societies have an imperative role in ensuring household food security via creating employment; providing financial and material support to poor people; distributing farm input and consumer commodities in the appropriate place and reasonable price; and supplying of missing services (e.g. grinding mill services) to rural and remote areas. Similar findings with other studies that show cooperatives are an important tool for increasing the incomes of their members (Simmon \& Birchall, 2008), generating employment (Merrett \& Walzer, 2001), and economic and social development of people living in rural areas (Toksoy, 2005).

They illustrated that cooperative societies have provided financial assistance (loan- or grant-based) to poor people, especially to women and youth unemployed. They have generated employment like store, accountant, seller, manager and so forth for unemployed persons. They have also actively participated in environmental rehabilitation through some biological and physical conservation, and others arranging training and panel discussion for awareness creation about the causes and consequences of environmental degradation. They have also organized practical and intensive training on self-employment and entrepreneurship. They have arranged exposure visits, experience sharing and panel discussion with the communities to enhance awareness about environmental rehabilitation, employment issue and women empowerment.

For example, members of Humera Multipurpose Cooperative Society have planted two trees per member per year since 2004 in highly degraded area, Menjaer hillside. More than 60000 indigenous and exotic seedlings have still planted with $73 \%$ survival rate. Rawuyan Irrigation Cooperative Society has also constructed $578 \mathrm{~km}$ long soil and water conservation, treated three big gullies, and distributed 20000 indigenous trees for the communities. Demelash Abraha, the manager, explained that the cooperative has spent about birr 2.3 million to implement the activities. $80 \%$ of the total costs were covered by a free labor contribution of the members while the remaining $20 \%$ from members, GTZ and REST.

The finding of this study is similar to the result of other studies. The empirical studies found cooperatives are the basis for food security and poverty reduction (Maghsoudi, 2006 \& Peng, 2007), for rural development and structural transformation of the agriculture industry in European Union, India, Malaysia and others third-world countries (Emelianoff, 1942, Bibby \& Shaw, 2005 \& Gijselinckx \& Develtere, 2008), for provision of market access and essential services (Zeuli, 2002 \& Cheung 1969), and empowerment of poor people and protection of environmental degradation (Atmis, 2009, He, 2010 \& Özdemir, 2005).

Generally, the cooperatives have played significant roles in ensuring household food security in the study areas through increasing incomes, rising purchasing power and broadening livelihood opportunities. They have played positive roles in reducing unemployment, protecting environmental degradation, and stabilizing local markets. According to this study, awareness and knowledge is crucial instrument for rural people to organize in cooperatives. Concerned bodies should have to exert efforts in expanding infrastructure services like telephone, schools, road, electricity, information service centers, training institutions and others in order to join more rural people into the cooperatives and solve their common economic and social problems collectively.

\section{Concluding Remark}

The study aimed at investigating the roles that agricultural cooperatives have played in ensuring household food security through household survey, desktop survey and Heckman food security model. The study found that the cooperatives have generated a significant employment opportunities for unemployed people across the study areas. It also shows that there are significant income and expenditure difference between cooperative members and nonmembers at 5\% significance level. Member households have on average earned birr 8600 from 2009-2010 and spent about birr 6000 on food and nonfood items whereas the figures for nonmember households are birr 5800 and 4500, respectively.

The study compared the income and expenditure of member households of 2009-2010 years with the baseline year. The inter-member mean comparison approach shows that there is statistically significant difference in the incomes and expenditure of the members between the two periods. The mean household income and expenditure difference were about Birr 3700 and 1900, respectively. The group discussion and household survey proves that the positive changes in their incomes and expenditure as a result of the cooperative societies have enabled them to send children to schools, cover medical expenses, take balance diet and cover other expenses.

The average per-adult-equivalent household income per annum during 2009 and 2010 for the 
members was Birr 1866 while the corresponding figure for nonmember households was Birr 1228 . Similarly, the average per-adult-equivalent expenditure per annum during the same years for members was Birr 1296 and for nonmembers Birr 950. Given the estimated Birr 900 per-adult-equivalent per annum as a food poverty line in the country, the study found that $21 \%$ of the member households are food insecure while the figure for the nonmember households is $36 \%$. This shows member households are more food secure than nonmembers as well as the number of food secure people are higher for members (79\%) than nonmembers $(64 \%)$.

The cooperative participation model of the study produced that special skill, membership in rural association, participation in public meeting, household education, obtaining cooperative-related training, having information access ( $\mathrm{TV}$, radio, mobile), availability of to rural infrastructure services, farmland holding sizes, and farmland ownership are explanatory variables that have statistically significant probability to influence rural households to join into cooperative societies in the village. For instance, households with $\mathrm{TV}$, radio or mobile have $93 \%$ higher probability to become a member of cooperative societies compared to households with no information access. Similarly, households who are members in rural association have higher probability with $29 \%$ to join cooperatives than households who are not members.

The cooperative food security equation of the Heckman model shows that cooperatives are important instrument for household food security. The major and statistically significant determinants of household food security are farmland sizes, number of oxen, livestock (TLU), household age, member in cooperative society, household education, family sizes, access to main market and potable water, and availability of infrastructure services like road, extension, electricity and communication services. The cooperatives societies in the study area have played indispensable and positive roles in ensuring household food security.

Generally, food insecurity is a recurrent and common problem of the Tigray region (Ethiopia). Empirical literatures and this study indicate that cooperative societies have played significant and positive roles in reducing food insecurity problem. Accordingly, the government and other concerned organizations should provide technical and financial support to cooperative societies so as to facilitate the strengthen, growth and diversification cooperative societies thereby play their essential roles in ensuring household food security and brining sustainable development in the region and in the country as a whole.

\section{Acknowledgment}

The corresponding author thanks the rural people of the Tigray region for all their kind support and positive cooperation during the household survey.

\section{Note}

1. There is no scientific standard conversion factor of tsimad to hectare. Customary, however, four tsimad is considered as one hectare.

\section{Reference}

Andrew, K. (2001). Trust building, trust breaking: The dilemma of NATO Enlargement, J. Int. Organ. 55 (4), 801-828.

Atmis, E., Günşen, B., Lise, B. \& Lise, W. (2009). Factors affecting forest cooperative's participation in forestry in Turkey. Forest Policy and Economics, 11(2), 102-108.

Baviah, M. (2006). Microfinance for women empowerment and gender Equality: Experiences of some Asian countries and lessons for Ethiopia. Biannual Conference of the Association of Ethiopian Microfinance Institutions (AEMFI) Hosted by Dedebit Credit and Saving Institutions (DECSI), Mekelle, Ethiopia.

Bhatta, B. (2004). Socioeconomic transformations and road accessibility: Evidence from Northern Ethiopia. Department of Economics and Resource Management, Norwegian University Of Life Sciences, Norway.

Bhuyan, S. (2000), Grower and manger issues in fruit and vegetable cooperatives. Paper Presented at NCR-194 Annual Meeting, December 13, 2000, Las Vegas, Nevada. Retrieved from: http://www.agecon.ksu.edu

Bibby A. \& Shaw, L. (2005). Making a difference: Cooperatives solutions to global poverty, Manchester: Cooperative College.

Birchall, J. (2004). Cooperatives and the millennium development goals: Impacts and challenges. Geneva, Switzerland, ILO Press. Retrieved from: http://www.copac.coop

Broussard, N. (2012), Food aid and adult nutrition in rural Ethiopia. Agricultural Economics, 43, 45-59.

Carlson, J., Andrews, S., \& Bickel, W. (1999). Measuring food insecurity and hunger in the United States: Development of a National Benchmark Measure and Prevalence Estimates. Journal of Nutrition, 129, 510 - 516.

Cheung, S. (1969). Transaction costs, risk aversion and the choice of contractual arrangements. Journal of Law and Economics, 12(1), 23-42.

Coon, C. \& Leistritz, L. (2001). Economic contribution of North Dakota cooperatives make to the state economy. AE20011 Department of Agricultural Economics, North Dakota State University.

CSA (2011). Annual report of Ethiopian economy by Central Statistics Authority of Ethiopia. Retrieved from: http://www.csa.gov.et.

Dayandiach, W. (2004). Cooperatives and rural development: Success, failures and prospects of cooperatives experiences from the rural areas of the Republic of the Sudan, Presented in the Annual Conference of Cooperative Societies in Ethiopia, Selam Publishing Private Limited, Addis Ababa, Ethiopia.

Dongfeng, S. (2012). Research on the Impact of Cooperative Behaviors in Alliance Organization in Member Psychological Contract. African Journal of Business Management Vol. 6(29), 8737-8742 
Emelianoff, V. (1942). Economic theory of cooperation: Economic structure of cooperative organizations. Reprinted by the Center for Cooperatives, University of California, Davis, California, USA, 1995

Fairbairn, B. (1999). Cooperative development and the state: Case studies and analysis. Research report to the cooperatives secretariat, Government of Canada.

FCC (2006). Five year development plan, Federal Cooperative Commission of Ethiopia. Addis Ababa, Ethiopia.

Fitsum, H (2003). Poverty, institutions, peasant behavior and conservation investment in Northern Ethiopia: Doctor Scientiarum Theses 2003: 22 Agricultural University of Norway.

Fitsum, H. (2003). Promising future for rural cooperatives in Ethiopia? Reflections on the experience in cooperative movement in 1970s -1980s. Presented in the Annual Conference of Cooperatives in Addis Ababa, Ethiopia. Retrieved from: http://www.aau.edu.et.

Gijselinckx, C. \& Develtere, P. (2008). The cooperative Trilemma: Cooperatives between market, state and civil society, Working Papers on Social and Cooperative Entrepreneurship WP-SCE 08-01.

Glasbergen, P. (2000). The environmental cooperative: Selfgovernance in sustainable rural development, Journal of Environment and Development, 9 (3).

Greene, W. (2002). Econometric analysis, $5^{\text {th }}$ Edition, Upper Saddle River, New Jersey 07458, New York University

Groves, F. (1985). What is cooperation? The philosophy of cooperation and its relationship to cooperative structure and operations. UCC Occasional Paper, No. 6, University of Wisconsin Center for Cooperatives.

Guest ED (2004). The psychology of the employment relationship: An analysis based on the psychological contract. Appl. Psychol, 53, 541-555.

Hallett, P. (2001). The car sharing cooperative of Edmonton: Paving the way to a greener future, Synergy, 10 (1).

He, G. (2010). An explanation for rural mutual financial cooperatives mechanism and performance, the Chinese Cooperative Economic Review, 1 (1), 15-27.

ICA (2005). Cooperative and development: International Cooperative Alliance, Annual Report, Retrieved from: http://www.ica.coop

Kebeer, N. (2005). Resources, agency and achievements: Reflections on the measurement of women's empowerment development and change, Vol. 30, Institute of Social Studies, Oxford, UK.

Lee, Y. J. (2001). National forestry cooperatives federation in Korea. Review of International Cooperation, 94(2), 32-36.

Maghsoudi, A. (2006). The role of cooperatives in developing and sustaining local and regional communities. Review of International Cooperation, 99(1), 70-76.

Max, E., Daniel, N. \& Melissa, B. (2011). Effects of eye images on everyday cooperative behavior: A field experiment. Evol. Hum. Behav, 32(3), 172-178.

Merrett, C., Walzer, N., Holmes, M. \& Roger, B. (2001). New generation cooperatives: Alternative measures of success. illinois institute for rural affairs presentation at Madison, WI, Value-Added Conference.

Mitiku, H., Herweg, K. \& Stillhardt, B. (2006). sustainable land management- A new approach to soil and water conservation in Ethiopia,

MoFED Report (2011). Five years (2010/11 - 2014/15) strategic plan of Ethiopia: Growth and transformation plan, Prepared by the Ministry of Finance and Economic Development. Retrieved from: http://www.mofed.gov.et.

Özdemir, G. (2005). Cooperative-shareholder relations in agricultural cooperatives in Turkey. Journal of Asian Economics, 16, 315-325.
Peng, K. (2007). Singapore-the host for the international cooperative, Alliance General Assembly 2007. Review of International Cooperation, 100(1), 24-32.

Pérotin, V. (2006), Entry, exit, and the business cycle: Are cooperatives different? Journal of Comparative Economics, 34 (2), 295-316.

Pichiavaram, D. (2003). Cooperative practice in welfare improvement of poor rural members: Irrigation and multipurpose cooperatives, New Delhi, India.

RSA (2005). Co-operatives bill. portfolio committee on trade and industry (National Assembly), B 4B - 2005, Cape Town, South Africa.

Rueben, B. \& Salathe, L. (1978). Adult-equivalent scales: An alternative approach, American Journal of Agricultural Economics, 60 (3), 460-468.

Sendalo, D. (1995). Tethering of goats in Tanzania. Purpose and Implications with Special Reference to Effects on Grazing Behavior and Intake. PhD University of Reading, Department of Agriculture, United Kingdom.

Simmons, R. \& Birchall, J. (2008). The role of cooperatives in poverty reduction: Network Perspectives. Journal of Socioeconomics, 37 (6), 2131-2140.

Smeeding, M., Michael, O. \& Lee, R. (1990). Poverty, inequality and income distribution in comparative perspective, Urban Institute Press.

Sobrado, M. (2000). From navies to entrepreneurs: The OW in Costa Rica. In a Future for the Excluded. Edited by Raff Carmen and Miquel Sobrado, London, Zed Books.

Tadesse, B. (2002). Cooperation and cooperatives: Their roles in socioeconomic development. Annual Conference of Ethiopian Economic Association, Addis Ababa.

Tanguy B., Alemayehu S., \& Eleni G. (2008). Impact of cooperatives on smallholders' commercialization behavior: Evidence from Ethiopia, Agricultural Economics, 39, 147-161

Tarasuk, S. (2001). Household food insecurity with hunger is associated with women's food intakes, health and household circumstances. J Nutr, 131, 2670-2676

Todaro, M., \& Smith, S. (2011). Economic development, 11 (Ed), Addison-Wesley, Pearson.

UNDAW (2001). Empowerment of women throughout the life cycle as a transformative strategy for poverty eradication, United Nations Division for the Advancement of Women. Department of Economic and Social Affairs. Report of the Expert Group Meeting, 26-29 November. New Delhi, India

Van Der Walt (2005). The resuscitation of the cooperative sector in South Africa. Paper Prepared for the International Cooperative Alliance XXI, International Cooperative Research Conference, Cork, Ireland, August 11-14, 2005.

Vargas, R., Bernard, T., \& Dewina, R. (2008), Cooperative behavior in rural Uganda: Evidence from the Uganda National Household Survey 2005. Markets, Trade and Institutions Division, International Food Policy Research Institute, Washington, DC, USA

Veerakumaran, G. (2003). Role of cooperatives in food security: A case of Ethiopia, Mekelle University, Retrieved from: www.eeaecon.org/5th\%20inter\%20papers/dr.g.veerakumaran $\% 20-\% 20$ eeamucoop 1 .htm

Walter, R. (2003). The process discursive approach to community economic development. Community Development Journal, $38(2)$.

Zeuli, K. (2002). The role of cooperatives in community development, University of Wisconsin Center for Cooperatives, Bulletin No.3.

Zhao, L. \& Xuchu, X. (2011) Credit cooperatives: A miracle solution for poverty reduction in rural China. Paper submitted to the $2^{\text {nd }}$ EURICSE Conference on Cooperative Finance and Sustainable Development, 9-10 June 2011, Trento, Italy 